Journal of Sustainable Development of Transport and Logistics

journal home page: https://jsdtl.sciview.net

Onwuegbuchunam, D. E. (2020). Port deregulation and productivity in Nigeria: Some

implications for economic regulators. Journal of Sustainable Development of Transport and

Logistics, 5(1), 133-140. doi:10.14254/jsdtl.2020.5-1.13.

\title{
Port deregulation and productivity in Nigeria: Some implications for economic regulators
}

\section{Donatus E. Onwuegbuchunam}

Department of Maritime Management Technology, Federal University of Technology Owerri, P.M.B 1526, Nigeria

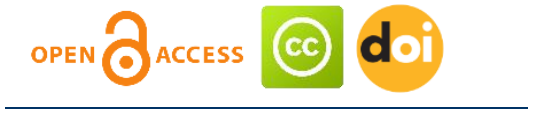

Article history:

Received: March 12, 2020

1st Revision: March 29, 2020

Accepted: April 28, 2020

DOI:

10.14254/jsdtl.2020.5-1.13

\begin{abstract}
Regulation in seaports broadly covers port safety, security, pollution and terminal operations which generally fall within the purview of national government's administrative authority. Port deregulation policy in the era of global port reforms beginning in 1990's, was introduced to limit government interference in commercial aspects of port operations, attract private sector funding and improve port productivity etc. However, in unregulated port market environment, the involvement of private sector in port terminal management can arguably generate risk of collusion especially among terminal operators offering the same or similar services. This paper examined port user welfare following private sector participation in a deregulated port environment. The Nigeria's port terminal concession policy implementation was analysed as case study. From the findings, we demonstrated the essence for and role of economic regulator in ensuring that optimal port user welfare gains were achieved and maintained in post port reform regime.
\end{abstract}

Keywords: port deregulation, concession, productivity, privatisation, cargo throughputs

\section{Introduction}

Port Regulation consists of rules relating specifically to port operations and activities, prescribed by a competent authority and having the force of law. Port regulations include obligations and prohibitions and frequently comprise provisions on their enforcement. These rules have to ensure efficient functioning of the port as well as safety and security in port area. They may also serve other purposes, such as prevention of environmental pollution. Port regulations, and the way they are enforced, impact on a port's competitiveness. Over-regulation may have an adverse impact on a port's performance. Conversely, well-drafted regulations, accompanied by adequate enforcement, are likely to facilitate port operations and activities (Portius International, 2013).

Port regulation is necessary because ports are important in the following ways (according to excerpts from Burns, 2015):

Corresponding author: Donatus E. Onwuegbuchunam

E-mail: don@futo.edu.ng

This open access article is distributed under a Creative Commons Attribution (CC-BY) 4.0 license. 
- they facilitate global and national trade and enable their clients to land their cargoes in their Free Trade Zones without the mediation of the customs officials;

- they serve as hubs and distribute commodities throughout the supply chain(s).

- they boost global economy through their contribution in the energy sector., in three different levels:

- Ports are the launching platforms where oil and gas logistics take place: they collect the required equipment, spare-parts and provisions on behalf of supply vessels.

- Crude oil is typically shipped through crude oil tankers or pipelines from the oil wells to refineries that are usually located in the vicinity of ports.

- Seaports' increasing investment in renewable energy, for example, offshore wind facilities. Modern wind energy technology is closely associated with port technology and operations hence ports are the ideal location not only for offshore farms but also for ashore wind farms in ports' land property

- Ports facilitate the operational missions of offshore-related ships such as survey and seismic vessels, diving support and construction ships, exploration jack-up rigs, semisubmersible rigs, anchor handlers (AHTSs), and emergency rescue recovery vessels (ERRVs).

\subsection{Port authorities and regulatory framework}

In order to retain its high standards of safety, security, environmental integrity etc. the maritime industry is heavily regulated for both port facilities and ships (Burns, 2015). Port regulation can be carried out at global, national and state or municipal level. At a global level, international organizations such as the International Maritime Organization (IMO), the International Organization for Standardization (ISO), the World Health Organization etc. have developed an efficient regulatory framework of a global radius that encompasses most nations. At national level: each nation adopts rules and regulations that reflect the international standards to a certain extent, yet their priority is to promote the national needs and goals. State or municipality regulations: additional regulations exist at a local level, depending on a nation's political regime and governance (Burns, 2015).

Some of the regulatory framework that port authorities and ships need to comply with includes Safety (ISM), Security (ISPS), Occupational Safety and Health (OSHA in the United States, or OHSAS in the rest of the world), ISO 14001: Environmental Protection by the ISO (Burns, 2015). Among these regulations, ISM and ISPS are adopted by the IMO, and their compliance is ensured at a national level for the 170 member states that have ratified the multilateral treaty as of 2013 (Burns, 2015). Certification and verification are components that most of these regulations have in common. Both ashore (i.e., company) and shipboard verification and certification are issued by recognized organizations (ROs), which are appointed to carry out the regulatory certification on behalf of flag administrations. Some of the leading ROs are members of the International Association of Classification Societies and include: the American Bureau of Shipping (ABS 2005), Det Norske VeritasGermanischer Lloyd Group (DNV-GL Group), Bureau Veritas (BV), Lloyd's Register (LR), Nippon Kaiji Kyokai (NK) (Burns, 2015); to mention a few.

\subsubsection{Commercial / Economic regulation of seaports}

Thus, while we have seen a brief of the general regulation of seaports as it relates to safety, security and environmental issues in port operations, the focus of this paper will be on economic regulation of seaports implemented via port concession policy. Port deregulation policy in the era of global port reforms beginning in 1990's, was introduced to limit government involvement in commercial aspects of port operations (Nigeria's case being a notable example). Port assets have in the past been regulated by national governments which naturally owned and managed them. This stems from the fact that ports are strategic assets to national security and economy. The large scale investments required in the provision of port assets and their "public good" nature means that only government can finance such investments. The increasing technological developments coupled with growing financial needs in the port sector left many governments with the choice of partial or total deregulation ports. Most national governments deregulated their ports in order to attract investment funds from private sector for modernising port facilities. 


\subsubsection{Forms of private sector participation after deregulation}

The following models according to Trujillo \& Nombela (2000) represent the forms of private sector participation in a deregulated port context:

i. Full Privatisation: All assets and liabilities are transferred to the private sector, which can be justified by serious fiscal needs from the public sector.

ii. Partial Privatisation: Transferring to the private sector parts of the seaport for their development by private operators (Build, Operate and Own, BOO).

iii. Concessions: Introducing private operator participation in the port in order to build or renovate facilities required for service provision (Build/Rehabilitate, Operate and Transfer, BOT or ROT).

iv. Joint Ventures: This type of agreement arises when two parties with common interests join forces. Thus, for example, in some cases a firm can supply technology and knowhow, while another might have knowledge of market opportunities and customer contacts.

v. Leasing: in some cases, port authorities simply rent port assets to be used by private operators during a fixed period, and thus they obtain income from contract fees.

vi. Licensing: in this case the port authority allows operators to provide some services which only require relatively simple equipment, and thus assets are generally owned by private operators.

vii. Management Contract: a simple form of introducing private participation in a port is by contracting out the port management. In this situation, the port authority is the owner of infrastructure and port facilities, but decisions on its running are taken by a private firm which can provide a more commercial approach to operations. Both investment and commercial risks are in this case faced by the public sector, since managers do not invest their own capital in the port.

When choosing among these options for port management, the extent of regulation to be applied will depend on evaluated objectives of the port administration (government), its constraints and whether port service to be provided requires exclusive use of infrastructure/superstructure or not. For example, some services like pilotage and berthing do not require exclusive use of port assets. However, they must be provided to port users to avoid service disruptions and for safety reasons. Services that require exclusive use of port assets require the use of scarce resources at seaports e.g. space. Within this group, we have terminals for cargo handling, storage areas, repairing docks and fuel suppliers. Here would-be operators need to use assets that are scarce and wholly owned by the government (or port authority). This is where concession is applied. The federal government of Nigeria opted for partial port deregulation in that it retained its regulatory capacity in matters of safety and security standards. It however, devolved its responsibility in commercial aspects of port operations to the private sector via terminal concessions.

\subsubsection{Concession contracts and regulatory requirements}

Concession contracts are suitable for port services that require exclusive of port assets. This form of contract is more common in Nigeria's port deregulation. When designing a concession contract, there are several aspects that must be carefully tailored; objective of concession, exclusivity in the use of assets, concessionaires' obligations and payments, term of concession, penalties and fines, and risk allocation. In all cases of contract adopted; License or Concession, the role of the regulator would be to ensure that standards (technical and operational) are maintained at price competitive rates and hence ensure that the welfare of port users are maximized (the World Bank, 2007).

\section{Concession and regulation of seaports in Nigeria: A case study}

Before the concession policy implementation, port authority in Nigeria lacked substantial capital (in foreign currency) required to upgrade port infrastructure and invest in new ones. Specifically, funding challenges led to the following problems: inadequate port storage capacity and navigational aids, bunching of vessels, limited cargo handling facilities, high down time of equipment, low labour 
productivity and shortage of storage space. As a way of introducing private investment in the port sector, the Nigerian government privatized the ports (albeit partially); adopting the "Landlord" approach; whereby the Nigeria Port Authority (NPA, custodian of Nigeria's ports) is responsible for port planning and regulatory tasks (related to safety, security and environment), and maintains ownership of port-related land and basic infrastructure. Under this arrangement, the private sector would be responsible for terminal operations, construction, purchase, and ownership of superstructure and equipment. Under this model, the NPA provides port infrastructure in the strict sense (lighthouses, quays, loading and unloading areas, etc.), while private companies supply the superstructure required to provide port services (office buildings, machinery, etc.). The NPA also determines the conditions for the private sector to operate by fixing tariff caps, number and type of terminals, concession terms and features among others, see Leigland \& Palsson (2007), Onwuegbuchunam (2014).

As at the year 2006, there were altogether twenty six terminals so far transferred to private operators which were expected to invest in facilities utilized in these terminals. Operation of port services by the private operators started immediately. The following analyses were extracts from port productivity assessment of Nigeria's ports partial deregulation programme as reported in Onwuegbuchunam (2014). In Table 1, we note that from the year 2002 to 2006, cargo throughputs averaged more than two times what they were in the two preceding periods. Although reforms (in form of commercialisation) had begun in the port sector, NPA was however, still involved in cargo handling operations. The concession reform in the year 2006 enabled the complete transfer of cargo handling functions from public to the private operators and had the latter invest in new cargo handling facilities. It is noteworthy in table 1 that from the years 2007 to 2013, (i.e. the post concession era), total cargo throughputs handled in the Nigerian ports thus averaged more than three times what it was in the three preceding periods examined. In terms of number of facilities at the ports, we see in table 1 that in the first three periods preceding concession reform, the average number of plants and equipment deployed for cargo handling at the ports declined from 67 to 60 (i.e. from the year 1991 to 2001). It came to 32 just before the reform in the year 2006 and peaked to 54 since the year 2007. The labour input in metric tons per gang hour proxy for crane efficiency dropped from 18 TNGH (Tons/Net Gang Hour) to $9 \mathrm{TNGH}$, since 2007. Two reasons may account for this result; either facilities in form of plants and equipment were not enough to cope with the increasing traffic attracted by the reforms or there were wilful delays meant to accumulate demurrage charges and hence enrich corrupt port workers as documented by Chikere (2014). According the statistics (in table 1) average ships turnround time in the ports has not decreased remarkably since the year 1991. It hovered in the range of 6 days during the study period. The result is not surprising given that crane efficiency (in the ports) on average deteriorated since 2007. This outcome implies that vessels may still be experiencing delays at the ports. This finding is consistent with UNCTAD's post port reforms assessment (see UNCTAD, 2011).

\section{Sources of productivity changes in Nigeria seaports}

Identification of sources of productivity changes is necessary in order to direct policy interventions to specific variables of interest. Productivity change can be attributed to two sources: Efficiency Change (effch) and Technical Efficiency Change (techch), see Malmquist (1953), Shepard (1970), Fare, Grosskopf, Lindgren \& Roos (1992) and Halkos \& Tzeremes (2012). The numerical values of these indices based on Nigeria ports' study are presented elsewhere (see Onwuegbuchunam, 2014) in a format emphasizing relevant reform regimes of interest. Based on the findings, we note that in the pre-concession era, average total factor productivity index was optimal yielding an approximate index of 1.205. According to Färe, Grosskopf, Norris and Zhang (1994), a total factor productivity index greater than 1 (say 1.25) signals a productivity gain. Considering the components of total factor productivity, we note that these components namely efficiency change and technical change recorded average values of 1.032 and 1.311 respectively. These values are also optimal. We observe the same pattern of productivity changes in the concession reform era. The scenario in productivity indices observed so far was also replicated in the post reform regime. 


\begin{tabular}{|c|c|c|c|c|c|}
\hline YEAR & Variable & Mean (values) & Std. Dev. & Min & Max \\
\hline \multirow{7}{*}{$\begin{array}{l}\text { L2 } \\
\sigma \\
\stackrel{-}{\sigma} \\
\sigma\end{array}$} & Total throughput (mt) & $1,190,539$ & $1,797,404$ & 22,952 & $7,948,369$ \\
\hline & General cargo (mt) & 499,426 & 687,354 & 5 & $3,378,057$ \\
\hline & Dry bulk cargo (mt) & 283,785 & 408,098 & 2 & $1,597,622$ \\
\hline & Liquid bulk (mt) & 407,328 & 875,143 & 2 & $3,306,711$ \\
\hline & Plants \& Equip (nos) & 67 & 50 & 2 & 188 \\
\hline & Labour (TNGH) & 18 & 10 & 7 & 53 \\
\hline & Turnround time (days) & 6 & 4 & 2 & 20 \\
\hline \multirow{7}{*}{ 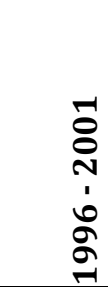 } & Total throughput (mt) & $1,961,315$ & $2,625,472$ & 1,021 & $11,500,000$ \\
\hline & General cargo (mt) & 626,047 & 736,483 & 2 & $2,575,729$ \\
\hline & Dry bulk cargo (mt) & 533,249 & 909,896 & 2 & $4,937,497$ \\
\hline & Liquid bulk (mt) & 802,019 & $1,567,165$ & 2 & $7,165,676$ \\
\hline & Plants \& Equip. (nos) & 60 & 43 & 1 & 215 \\
\hline & Labour (TNGH) & 18 & 14 & 6 & 65 \\
\hline & Turnround time (days) & 6 & 4 & 2 & 16 \\
\hline \multirow{7}{*}{ 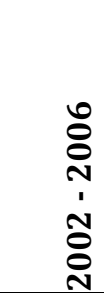 } & Total throughput (mt) & $3,630,678$ & $4,179,458$ & 35,020 & $15,100,000$ \\
\hline & General cargo (mt) & $1,060,012$ & $1,189,730$ & 84 & $4,531,664$ \\
\hline & Dry bulk cargo (mt) & $1,225,933$ & $1,722,760$ & 3 & $6,981,768$ \\
\hline & Liquid bulk (mt) & $1,344,733$ & $2,383,420$ & 2 & $9,330,409$ \\
\hline & Plants \& Equip. (nos) & 32 & 19 & 2 & 81 \\
\hline & Labour (TNGH) & 19 & 14 & 7 & 70 \\
\hline & Turnround time (days) & 7 & 5 & 1 & 23 \\
\hline \multirow{7}{*}{ 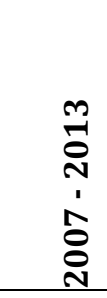 } & Total throughput (mt) & $9,589,885$ & $15,500,000$ & 52,943 & $102,000,000$ \\
\hline & General cargo (mt) & $2,815,978$ & $2,917,746$ & 2 & $8,131,734$ \\
\hline & Dry bulk cargo (mt) & $1,728,835$ & $2,304,634$ & 2 & $8,293,197$ \\
\hline & Liquid bulk (mt) & $5,045,072$ & $13,200,000$ & 41,788 & $89,900,000$ \\
\hline & Plants \& Equip. (nos) & 54 & 14 & 26 & 83 \\
\hline & Labour (TNGH) & 9 & 3 & 3 & 19 \\
\hline & Turnround time (days) & 6 & 3 & 2 & 11 \\
\hline
\end{tabular}

Source: Onwuegbuchunam (2014)

In Fig. 1, we see a clearer representation of the productivity change indices that occurred in the ports according to Onwuegbuchunam (2014). The graph shows that even though on average productivity indices improved during the study period, this was due largely to growth observed in the Western based ports. Based on the foregoing discussion, we conclude that there were significant changes in the components of productivity changes. This is to say that efficiency change and technical changes were significant sources of total factor productivity changes observed in the ports during the study period. Improvements in efficiency change captures changes in relative efficiencies over time i.e. it indicates whether port service production is getting closer (catching up) or farther from the frontier. In Nigeria's port concession programme, we would expect the managerial expertise brought about by the terminal operators to be reflected in changes in efficiency as well. This follows from the fact that observations are compared to the best practice frontier. Technical change on the other hand measures the capacity of port managers to optimally select and combine inputs in port production. More technically, it measures effects of innovation (brought about by the concession programme) in the management of ports. 
Figure 1: Distribution of productivity change indices (1991-2013) by location of ports

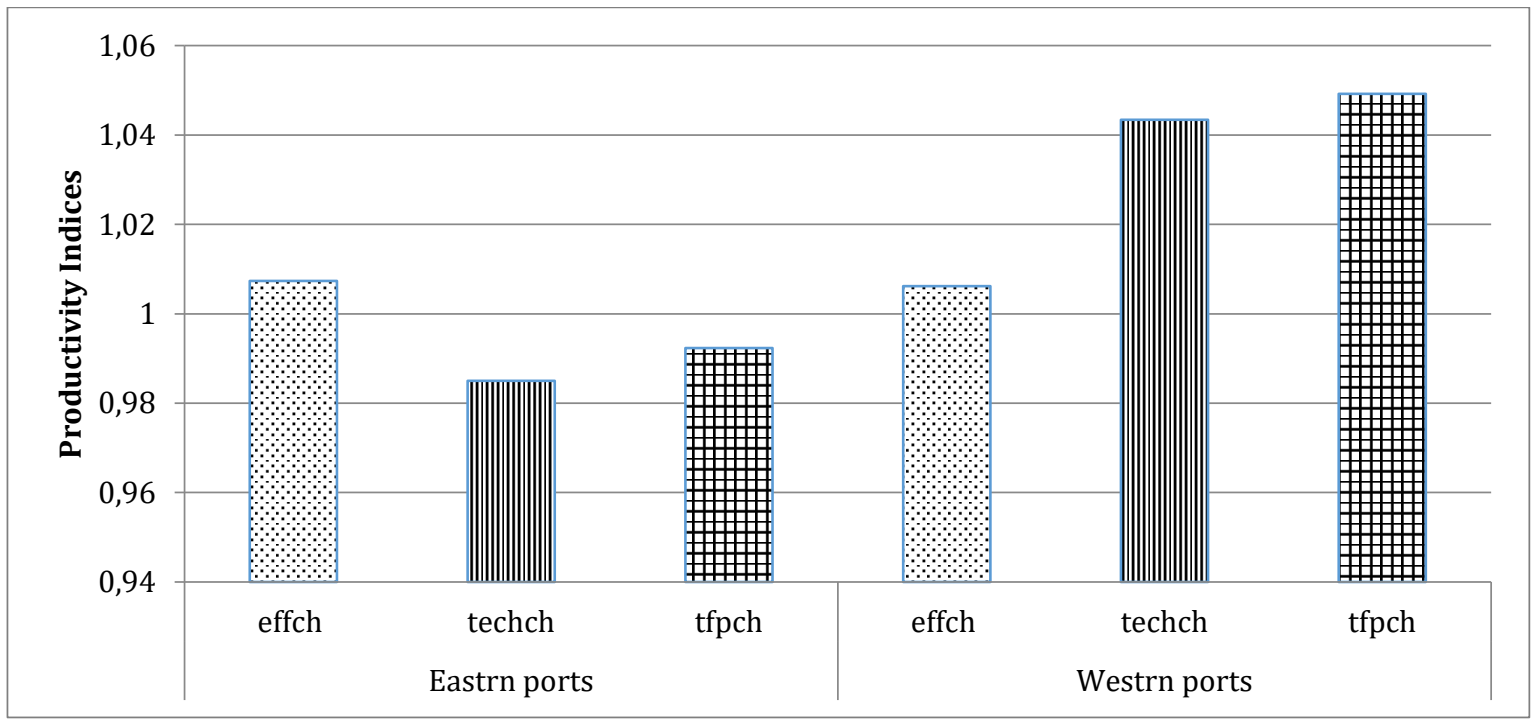

Source: Onwuegbuchunam (2014)

\section{Discussion of findings}

We summarize the major findings as: there were significant productivity (technological) changes in the three reform phases examined namely; pre-reform, reform and post reform eras. The changes observed became pronounced from the years 2009 to 2013 which fell into the post concession reform phase. The sources of these changes are attributable to efficiency change and technical efficiency change. It was also found that ports located in the Western part of Nigeria experienced pronounced productivity growth than the others in the other locations. These ports namely: Apapa, Container terminal, Tincan Island and RoRo port however constituted more than sixty percent of all examined. It is important to note that since only Western based ports performed efficiently; the relative efficiency gains arising from the concession reforms cannot be considered as being geographically distributed. Therefore optimal port user welfare gains have not been achieved from the concession reforms. This conclusion is supported by Chikere (2014), who posits that there are complaints about pricing and quality of service offered in the ports in the post reform era.

According to UNCTAD (2011), in spite of modest achievements achieved by the port operators, the following constraints persist:

- Shipping tariffs are higher than pre-reform levels.

- Slow response by NPA to port infrastructure and maintenance needs.

- Failure of certain operators to fully implement investment and development plans or fulfil financial obligations to the government.

- Problems with the state of assets and property handed over by the NPA.

- Persistent anti-competitive behaviour.

- Industrial actions over implementation of new labour regimes.

- Continued cargo clearance delays and issues with customs and cargo inspection.

- Failure of some investors to fully implement investment and development plans or fulfil financial obligations to the government.

\section{Recommendations}

Based on the above major findings, the following recommendations are made:

i. That given that significant productivity changes observed in Nigeria's seaports after concession were based on contribution from ports located in Western part of Nigeria, policy interventions should aim to improve productivity in Eastern ports so as to maximise port users overall welfare gains. In practical terms port regulator appointed should encourage competition based on price and service quality attributes to evenly distribute 
traffic. This would ensure efficient utilisation of resources (labour and capital) and improved throughput per turnround time.

ii. In guaranteeing effective utilisation of facilities to improve productivity, it is noteworthy that the present level of cargo handling facilities at the port is not adequate enough to meet cargo handling demand. This can be inferred from table 1 which indicates that cargo handling plants and equipment have maintained a steady decline since 1991 until the year 2007 when it started rising up (albeit marginally). Provision of adequate cargo handling plants at the ports is thus encouraged as this will shore up labour productivity which is at a minimum according to Table 1.

Closer monitoring of the terminal operators should be encouraged to ensure that quality services are offered at reasonable costs. The port regulator has a lot to do in monitoring the activities of terminal operators at the ports. The present situation at the ports leaves room for collusive tendencies among the foreign based operators who are disposed to dominate given their expertise and level of facilities deployed for port services. To avoid monopolistic tendencies, the appointment of independent port economic regulator has become imperative.

\section{Funding}

The authors received no direct funding for this research.

\section{Citation information}

Onwuegbuchunam, D. E. (2020). Port deregulation and productivity in Nigeria: Some implications for economic regulators. Journal of Sustainable Development of Transport and Logistics, 5(1), 133-140. doi:10.14254/jsdtl.2020.5-1.13.

\section{References}

Burns, M. G. (2015). Port Authorities and Regulatory Framework. Port Management and Operations. CRC Press, Taylor \& Francis Group, Parkway, New York.

Chikere, C. C. (2014). Nigerian Ports: The perils of demurrage. Nigeria Daily Independent Newspaper. Retrieved 20/09/14 from http://dailyindependentnig.com/2014/09/nigerian-ports-perilsdemurrage/.

Färe, R., Grosskopf, S., Lindgren, B., \& Roos, P. (1992). Productivity changes in Swedish pharamacies 1980-1989: A non-parametric Malmquist approach. Journal of productivity Analysis, 3(1-2), 85101.

Färe, R., Grosskopf, S., Norris, M., \& Zhang, Z. (1994). Productivity growth, technical progress, and efficiency change in industrialized countries. The American Economic Review, 84(1), 66-83. Retrieved from http://www.jstor.org/stable/2117971.

Halkos, G., \& Tzeremes, N. (2012). Measuring seaports' productivity: A Malmquist productivity index decomposition approach. Retrieved from http://mpra.ub.uni-muenchen.de/40174/.

Leigland, J., \& Palsson, G. (2007). Port Reform in Nigeria, Grid Lines, No. 1, Private Infrastructure Advisory Facility (PPIAF), The World Bank, Washington DC, USA.

Malmquist, S. (1953). Index numbers and indifference surfaces. Trabajos de estadística, 4(2), 209-242.

Onwuegbuchunam, D.E (2014). Productivity and Efficiency in Nigeria's Seaports: A Production Frontier Analysis. Unpublished Ph.D. Thesis, Federal University of Technology Owerri, Nigeria.

Portius International and EU Law Centre. (2013). Draft Chapter on Port Regulations for the IAPH Introduction to Maritime Law for Port Officials. Commissioned by Havenbedrijf Rotterdam NV.

Shephard, R.W. (1970). Theory of Cost and Production Functions. Princeton, NJ: Princeton University Press.

Trujillo, L., \& Nombela, G. (2000). Seaports in Estache, A., De-Rus, G. (Eds.), Privatization and Regulation of Transport Infrastructure, Guidelines for Policymakers and Regulators, WBI Development Studies, the World Bank, Washington, DC. 
UNCTAD. (2011). How to utilize FDI to improve transport infrastructure - ports: Lessons from Nigeria, (ed.). Best Practices in Investment For Development: Case Studies In FDI. The United Nations, New York and Geneva. Retrieved from http://unctad.org/en/Docs/diaepcb2011d8_en.pdf.

World Bank. (2007). Port Reform Toolkit, $2^{\text {nd }}$ ed. Public Private Infrastructure Advisory Facility, World Bank Publication. Retrieved from https://ppp.worldbank.org/public-privatepartnership/library/port-reform-toolkit-ppiaf-world-bank-2nd-edition.

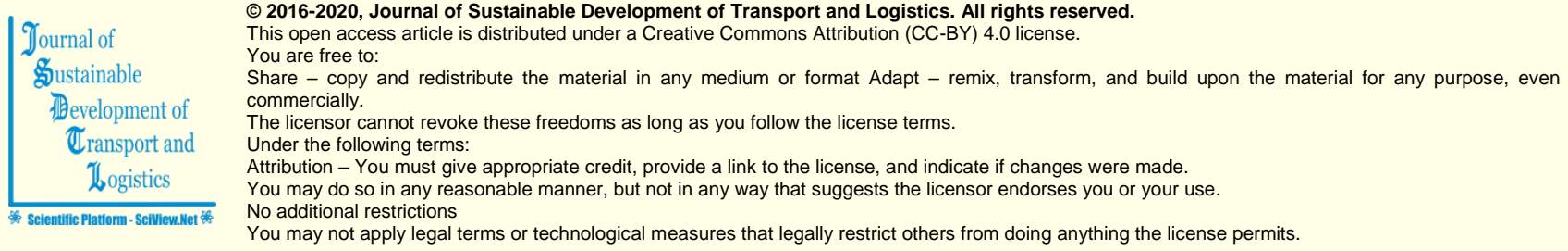

Journal of Sustainable Development of Transport and Logistics (ISSN: 2520-2979) is published by Scientific Publishing House "CSR", Poland, EU and Scientific Publishing House "SciView", Poland, EU

Publishing with JSDTL ensures:

- Immediate, universal access to your article on publication

- High visibility and discoverability via the JSDTL website

- Rapid publication

- Guaranteed legacy preservation of your article

- Discounts and waivers for authors in developing regions

Submit your manuscript to a JSDTL at https://jsdtl.sciview.net/ or submit.jsdtl@sciview.net 